Kóródi Márta - Bakos Róbertné - Kalmárné Rimóczi Csilla - Savella Orsolya - Mondok Anita - Németh Miklós

\title{
A helyi termékek interpretációs lehetőségei és szerepük a desztináció fejlesztésben
}

Kóródi, Márta - Bakos, Róbertné - Kalmárné Rimóczi, Csilla - Savella, Orsolya - Mondok, Anita-Németh, Miklós: Interpretative Possibilities of Local Products and their Role in the Development of Tourism Destinations

Rural tourism is a progressively growing factor of local economy in Europe. For this, those products of rural tourism are needed that are based on direct rural attractions like natural facilities, technical attractions, demonstration of special activities. The examination which is presented above is about the products of rural tourism. It examines the system of interactions between the effects of the development on products of rural tourism. In addition, it examines the effects of arrangements made in rural development on the development of tourism. In the future one way of the rural development can be the development of rural tourism giving a chance for alternative activities and ways of earning money. Among the several specialized tourism it is gastronomic tourism that is mostly based on tradition. It is very close to rural people, they can easily keep these traditions alive and they can think they are closed related with them. The gastronomical touristic offers of rural small regions and the natural curiosity of tourists can induce a development that can be $a$ base of conscious development of products.

Keywords: rural tourism, local products, interactivity, handkraft, gastromomy

\section{ÖSSZEFOGLALó}

A vidéki turizmus a helyi gazdaság egyre növekvő tényezője Európábana vidéki turizmus. A vidéki turizmus számára olyan termékelemekre van szükség, amelyek közvetlenül a vidéki élményen alapulnak, mint például a természeti adottságok, a technikai látnivalók, vagy a különleges tevékenységek bemutatói. A vizsgálat ezeket a termékeket elemzi, összegyűjtve az interpretációs módszereket, amelyek különösen a vidéki turizmusban jellemzőek. A vidéki turisztikai termékfejlesztés hatásai közötti interakciós rendszereket vizsgálja a kutatás. Ezen kívül elemzi a vidékfejlesztés és a turizmusfelesztés kölcsönhatását. A vidék jövőjének egyik útja lehet a vidéki turizmus fejlesztése, lehetőséget adva alternatív tevékenységek végzésére és ezáltal jöveledelmszerzésre. Többek között ide tartozik a gasztronómiai turizmus, ami fóként a hagyományokon alapul. Nagyon közel áll a vidéki emberekhez, együtt élnek a hagyományokkal és könnyen azonosulnak vele. A turistát a természetes kiváncsiság hajtja, hogy megkóstolja a vidéki kistérségek gasztronómiai ajánlatait. $E z$ a kereslet indukálhatja a fejlődést és a további tudatos termékfejlesztést.

Kulcsszavak: vidéki turizmus, helyi termékek, interaktivitás, kézművesség, gasztronómia

\section{BeVEzetés}

„Ahol elvesznek a tradíciók, ott kilyukad az idő, elpereg a múlt." (Ancsel Éva)

A turisztikai desztinációfejlesztési koncepciókban a népi hagyományok, kézművesség fejlesztése általában megjelenik, több desztináció 
esetében jelentős szerepet kap. Több évvel ezelőtt a vidéki területekre koncentrálódott a helyi termékek kínálata és jelentősen összefonódott a folklórral. Manapság a terület, a desztináció sajátosságai kerületek előtérbe, a vidékiség megjelenése nem elsődleges, a helyi alapanyagok és a kézi megmunkálás jelenti az értéket a helyi termékekben. Emellett, amenynyiben a desztináció vidéki jellegű, a vidéki sajátosságokat is elvárja a látogató. A termelés, készítés, szolgáltatás helyének, és a termelő, készítő, szolgáltató beazonosíthatósága teremti meg a hitelességet, a helyi termék élményét. A helyi termékek, szolgáltatások turisztikai hasznosítása a hagyományokra épít, a helyi lakossághoz közel áll, vele könnyen azonosulhatnak, mert a gyökereikkel, a tárgyi kultúrával kapcsolatban érintettnek érzik magukat. A mai vidéki közösségek is vágynak a hagyományokra, hamar elfogadják az új hagyomány teremtésére irányuló törekvéseket. A desztináció új és sikeres rendezvényeit beépítik saját hagyományrendjükbe. A kutatás a helyi termékek és szolgáltatások kínálatának és kiajánlásának sajátosságait vizsgálja magyar, svájci és francia desztinációkat vizsgálva, azonosságokat és különbözőségeket feltárva helyszíni terepmunkán felvett adatok alapján.

\section{KUTATÁSI ELŐZMÉNYEK}

A nemzeti hagyományok őrzésének két legfőbb módja szorosan összekapcsolódik, az egyik a kézművesség hagyományainak ápolása, a másik a gasztronómiai hagyományok ápolása. . Egy ország kézmüvessége attól lesz nemzeti, hogy a helyi lakosság a mindennapjaiban éli. A kézmüves kultúra a mindennapokhoz hasonlóan a turizmusban is mindig jelen van. A turistát a természetes kíváncsiság is hajtja, hogy megfogjon egy-egy edényt, tapintson szövést, megnézegesse a fény játékát a fonálon, kipróbáljon formázni vesszőt, vagy agyagot. Található olyan szegmens is, amelynek meghatározó motivációja a népi kézműves kultúra megismerése, az eredeti hagyományok megtapasztalása. A külföldi turistát a formák mellett az az életstílus ra- gadja meg, melynek szerves részei a kézmúves termékek. A kézműves hagyományok piacra vitelének eszközei közé tartoznak a kézműves rendezvények, a bemutatók, a nyitott múhelyek, az élő múzeumok, tájházak, mint legjellemzőbb turisztikai termékelemek. A turisták egyedi, különleges élményekre vágynak. A kézműves termékelemek a folklórral és a vidékiség sokszínűségével összekapcsolva igazi kuriózummá válhatnak. A magas színvonalú komplex turisztikai termékkínálat, amibe beleillik termékelemként a kézművesprogram feltétele a magas fajlagos költésű szegmens megszerzésének. Ahhoz hogy a turizmus vélt jelentős szerepét a vidéki életkörülmények javításában be tudja tölteni, a kézműves attrakciókból minél gazdagabb kínálatot kell kialakítani, amit vagy készen kínálnak komplex termékként, vagy a turista maga állítja össze a rendelkezésre álló termékelemekből.

\section{KÉZMŰVESVILÁG}

A magyarság tárgyi kultúráját a paraszti élet szükségletei és használata alakították célszerüvé. A parasztok a saját háztartásukban és a gazdaságukban szükséges használati, kultikus funkciójú vagy reprezentációs célú tárgyaikat maguk készítették alkalmanként vagy rendszeresen nemcsak saját használatra, hanem eladásra is. A kézműves a természet adottságait alakítja át sajátosan emberi célra, sajátossága, hogy anyagi és nem anyagi szükségleteket elégít ki. Jellemzőjük, hogy a tárgyak vagy eszközök díszítése anyagukkal és formájukkal teljesen összhangban van. A népi kultúra és a polgári kultúra eltérő stílusjegyekkel és díszítőjegyekkel bír. Népivé akkor válik, ha a nép elfogadja, áthasonítja, közösségébe iktatja. Az év bizonyos időszakában iparszerüen pl. a mezőgazdasági munka szünetében végzik, utána vásároznak, vagy őket keresik helyben a vásárlók. A kézműveskultúra bemutatóhelyei az élő múhely, bemutatómúhely, a műhelymúzeum, a termékgyűjtemény, a bemutatás folyhat a turista aktív részvételével vagy anélkül. 
Ha iparos kultúrája miatt népi iparos értékekben gazdag a kistérség, ez társul gyűjtőszenvedéllyel, az iskolák, müvelődési házak hagyománymegismerő, őrző és feltámasztó kezdeményezésével, "helyzetbe" kerülhet a település, kistérség létrejöhet az atelier-turizmus csírája. A tárgyalkotó népművészet hagyományainak közösségi továbbtanítása leképezi a régi nagycsaládokat, ahol generációk közös tevékenység során ismerték meg egymást, a múlt hagyományait, az alkotás örömét. $A$ népművészeten keresztül elsajátított néprajzi, történelmi, művészettörténeti ismeretek hozzájárulnak a magyar identitástudat megtartásához, az emberi kreativitás fejlesztéséhez, a természetes anyagok újbóli felfedezéséhez. A felkészített szakemberek résztvesznek a mikrorégió kézműves kulturájának újraélesztésében és terjesztésében. A térségben élők jelentős áldozatvállalási készségére lehet alapozni.

A kézművességet több szempontból lehet csoportosítani, alternatív jövedelemszerző ágak (fazekas, bőrtárgykészítés, kosárfonás, népi szabászat, csipke, gépi hímző, kovács, szőnyegszövő), hagyományos kézműipari ágak (csuhéfonás és csuhéjátékok, gyékénykötés, vászonkötés, kosárfonás) és a turizmusban értékesíthető termékek készítése (kézzel varrott tájegységi viseletekbe öltöztetett népi babák, népi ékszerek, ajándéktárgyak és játékok természetes anyagokból) ágai különböztethetők meg. A szakmák létszükségleti igényeket elégítenek ki, majd a civilizációs igények és a kulturális igények következnek.

Egy -egy területileg jól körülhatárolható térségben markánsan és jól izoláltan koncentrálódnak a kézműveshagyományok. A turisztikai teljesítményben azonban általában nem jelenik meg, kiemelkedő turisztikai potenciállal bíró térség nincs a jelentős kézműveshagyományokkal rendelkezők között, de nagyobb arányban fordulnak elő az átlagos, mint a gyenge turisztikai potenciállal bírók. Mindezek azt bizonyítják, hogy önálló vonzerőként még nem eléggé csábító a helyi termék-turizmus, komplettírozni kell a tartózkodáshoz kapcsolódó szolgáltatásokkal. Az átlagos kézművespotenciál nem is vonz igazán turistákat. Viszont a turisztikai potenciállal jellemezhető térségekben a kézműveshagyomány ápolásának élénkülése tapasztalható.

Egyértelmü a tennivaló, itt kell összefogni a térség szolgáltatóinak és komplex terméket alakítani a kézműves témára alapozva. $\mathrm{A}$ kevésbé gazdagabb területeken még kisebb az esélye a mühelyek vezető vonzerővé válásának, általában nem is helyi, hanem külső kezdeményezés indítja. Ezáltal tölthetik be a kézművesprogramokban célul kitűzött funkcióikat, a magyar vendégszeretet hagyományos jó hírének erősítése egy új és vonzó arculati elem kiépítése által, a hagyományok felelevenítése, az időbeni és térbeni koncentráció csökkenése, az élménydús program által a tartózkodási idő meghosszabbítása. A turisztikai kínálat bővítésével a kulturális örökség megőrzését és védelmét is szolgálják.

A látogatók számára az élményszerűség biztosítása több módszerrel történhet. A kézmüvesek többsége fontosnak tartja a bemutató interaktivitását, ezért különböző módszereket alkalmaznak. A jellemző interpretációs módszerek:

- a látogatók fényképezhetnek korlátozás nélkül

- a látogatók bármikor kérdezhetnek

- a látogatók kipróbálhatják a tevékenységet

- folyamatos magyarázat a bemutató közben

- a látogatók videózhatnak

- a bemutató megtekintése körbenállva

- a látogatók termékeket vásárolhatnak

- a látogatók hazavihetik a készített terméket

- a szakmai látogatóknak a bemutató után tapasztalatcserére van lehetőségük

- a látogatók a bemutató napján hosszú ideig (2-3 óra) is végezhetik a tevékenységet

- bemutató körbevezetéssel 
- bemutató megtekintése ültetve

- több helyszínen folyó bemutató

- a látogatók prospektust, szórólapot kapnak

- a látogatók ajándékot kapnak,

- a látogatók tanfolyamra jelentkezhetnek

- a látogatók alapanyagot is vásárolhatnak

- a látogatók a bemutató végén kérdezhetnek

- a látogatók részletes készítési útmutatót vásárolhatnak

- idegen nyelven is tudjuk kommentálni a bemutatót (angol, vagy német)

- a bemutatóhoz a szöveget idegen nyelven nyomtatva is megkaphatja a látogató

- a látogatókról fénykép készül (külön szolgáltatás)

- a bemutatóhoz magnóval biztosítunk idegen nyelvű magyarázatot

- a látogatók a tevékenységet és terméket bemutató prospektust vásárolhatnak

A szakmai látogatók a beszélgetések során a leggyakrabban a szakmai fortélyokról, technológiáról, a piacra vitelről, eladhatóságról, keresletről, az alapanyagokról, gépekről, berendezésekről, felszerelésekről érdeklődtek, ritkábban a vállalkozás indításáról, támogatásokról, elvétve a nyereségről, megtérülésről. A turisták érintett témái a beszélgetések során leggyakrabban a szakmai fortélyok, technológia, az indíttatás, családi hagyományok és a szakma tanulása, múvelése, ritkábban az alapanyagok, gépek, berendezések, felszerelések. A visszajelzéseket figyelik, szinte kivétel nélkül tudják, hogy mi tetszik leginkább a látogatóknak.

\section{ÖSSZEGZÉS}

A helyi termékeknek különleges funkciói vannak a térségek lakosságának, vállalkozásainak, turistáinak életében. Közülük legfőbb az öszszekapcsolás, ami inkább társadalmi szerepet jelent, mint gazdaságit. A termékkel az életének egy darabját adja az előállító a vendég kezébe, szolgáltatások esetén pedig hagyja, hogy részese lehessen a látogató a mindennapjainak. Összeköti a települések - sokszor 100 fős lélekszámot el nem érő falvak - lakosait. Büszkék az ügyes kezű mesterre, településük elhíresülhet az ismert kézművesről, így úgy érezhetik, hogy részük van a sikerben. A vállalkozóknak, kereskedőknek, továbbfeldolgozóknak pedig garancia a jó minőségű nyersanyag, az eredeti technológia, hagyományos gyártás. A desztinációk helyi termékei, szolgáltatásai sok, turisztikailag is eredményesen hasznositható lehetőséget rejtenek magukban, alkalmat adnak egyedi, exkluzív turisztikai termékek összeállítására is. A művészi színvonalú, élő és a vendéget foglalkoztató kézműves attrakciók lehetnek önálló termékek, de egyedüli tényezőként általában alacsony potenciállal bírnak a turisztikai teljesítmény, a vendégéjszaka szám növelésében, de jelentős szerepük lehet az alternatív jövedelemszerzésben.

„Valamiféle szépérzéket mozdít meg bennünk minden tárgy, amelyet emberi tíz ujj formált ki. Mintha a gölöncsér (fazekas) tíz ujjával is átplántált volna a teremtményeibe valami életet a magáéból."

Illyés Gyula

\section{Felhasznált irodalom}

[1.] Boross Marietta-Karácsony Zoltán-Tátrai Zsuzsanna (2004): Magyar népi kultúra, Képzőművészeti Kiadó, Budapest, pp. 7-17, 141-167.

[2.] Cros Kárpáti Zsuzsa: Az örökség társadalmi szerpe és felhasználása a területfejlesztésben, FVR 19985.

[3.] Hekliné Herbály Katalin: A népi mesterségek szerepe a Karcagi kistérségben. in: Kulcsemberek (szerk. Örsi Julianna), Turkevei Kulturális Egyesület, Túrkeve, 2002. pp. 145-167.

[4.] Örsi Julianna: Múló és születő hagyományok a Jászkunságon. in: Kulcsemberek (szerk.: Örsi Julianna), Turkevei Kulturális Egyesület, Túrkeve, 2002. pp. 267-278

[5.] Bogdán István: Kézmúvesek mestersége, Gondolat, Budapest, 1989.

[6.] Skrabut Éva: A népművészeti kézmúves hagyományok szerepe a vidékfejlesztésben, FVR 2001/8. 